\title{
THE CHANGING FORM OF THE INTERNATIONAL LAW COMMISSION'S WORK
}

\author{
Jacob Katz Cogan*
}

Sean Murphy's report ${ }^{1}$ on the sixty-fifth session of the International Law Commission (ILC) describes and analyzes the Commission's activities and decisions from last summer. He focuses his attention, as the Commission did, on the draft articles proposed by the Special Rapporteurs on the topics "immunity of state officials from criminal jurisdiction" and "the protection of persons in the event of disaster," as well as the Special Rapporteur's reported draft conclusions on the topic "subsequent agreements and subsequent practice in relation to the interpretation of treaties." Consideration of these proposals took up a significant amount of the Commission's time, and they will garner much commentary inside and outside governments, as befits their importance.

Here I focus on two elements of the Commission's procedure that, while noted in Professor Murphy's report, receive little attention generally: the final form that the Commission's work on a topic takes and what happens to that product once it is completed. The ILC Statute ${ }^{2}$ provides options and guidance on both issues, thereby giving the Commission some considerable flexibility to design its product as it deems appropriate. In the aggregate, the Commission's choices in this regard reveal much about how it views its role. As I will explain, the Commission's views appear to be changing.

One of the first things the Commission must consider once it begins its work on a new topic is the form that its eventual product will take-its "outcome" in Commission terminology. For most of its history, this product was typically (though not always) packaged, as Professor Murphy notes in a recent book chapter ${ }^{3}$, as "draft articles" - a phrase taken from the language of Article 20 of the ILC Statute. For example, the Commission's work on treaties (twice), diplomatic relations, consular relations, the diplomatic courier and the diplomatic bag, the immunities of states, the non-navigational uses of international watercourses, the succession of states (thrice), and state responsibility (discussed in further detail below) all took the form of draft articles. The term suggested that further work needed to be taken outside the Commission to turn the drafts into law, and what's more, that that work would be done by states through the process of negotiating a treaty. Draft articles were draft treaties.

One of the last decisions the Commission must take as it concludes its work on a topic is the recommendation that it will make to the UN General Assembly on what (if any) future action should be taken on the Commission's product. Though Article 23 of the ILC Statute provides the Commission with four options, again, for the greater part of its history, the Commission typically recommended that the Assembly convene a

* Jacob Katz Cogan is Judge Joseph P. Kinneary Professor of Law at the University of Cincinnati College of Law.

Originally published online 27 Mar. 2014.

${ }^{1}$ Sean D. Murphy, Immunity Ratione Personae of Foreign Government Officials and Other Topics: The Sixty-Fifth Session of the International Law Commission, 108 AJIL 41 (2014).

2 Statute of the Int'l Law Comm'n, G.A. Res. 174 (II) (Nov. 21, 1947).

${ }^{3}$ Sean D. Murphy, Codification, Progressive Development, or Scholarly Analysis? The Art of Packaging the ILC's Work Product, in RESPONSIBILITY OF INTERNATIONAL ORGANIZATIONS 29 (Maurizio Ragazzi ed., 2013). 
diplomatic conference that would use the completed draft articles as the starting point for the negotiation of a convention. Thus, in 1966, the Commission concluded its work ${ }^{4}$ on the law of treaties between states by "recommend[ing] that the General Assembly should convene an international conference of plenipotentiaries to study the Commission's draft articles on the law of treaties and to conclude a convention on the subject." And, in 1991, to take just one more example (among many), the Commission used the same language when it reported its work ${ }^{5}$ on the "jurisdictional immunities of States and their property." The recommendation made at the end of the Commission's work to convene a diplomatic conference was implicit in the form typically chosen by the Commission at the beginning: draft articles.

During the past fifteen years, the Commission's practice has shifted both at the front and back ends. Now, the outcome of the Commission's work is more likely than not to be described as something other than "draft articles," and the Commission's recommendation for General Assembly action is quite unlikely to be for the immediate convening of a diplomatic conference for the purpose of drafting a treaty.

The most well-known manifestation of the latter trend was the Commission's 2001 recommendation $^{6}$ to the Assembly that it "take note of the draft articles" on state responsibility and "consider, at a later stage, ... the possibility of convening an international conference .... with a view to concluding a convention on the topic." (For an important contemporaneous discussion, see David D. Caron's The ILC Articles on State Responsibility: The Paradoxical Relationship Between Form and Authority). ${ }^{7}$ It subsequently used the same formula when it completed the topics "responsibility of international organizations," 8 "effects of armed conflicts on treaties," and "law of transboundary aquifers ${ }^{10}$ adding a request in the latter instance that the Assembly "recommend to States concerned to make appropriate bilateral or regional arrangements for the proper management of their transboundary aquifers on the basis of the principles enunciated in these articles." The Commission's post-2001 practice has not been perfectly uniform, however. Thus, when it completed its work ${ }^{11}$ on diplomatic protection in 2006, the Commission, reverting to its customary practice, "recommend[ed] to the General Assembly the elaboration of a convention on the basis of the draft articles."

The move at the front end away from "draft articles," though, has been more recent. Many of the Commission's projects in the past fifteen years have taken that traditional form. In addition to the draft articles on state responsibility, draft articles have been produced on "diplomatic protection," the "responsibility of international organizations," the "law of transboundary aquifers," the "prevention of transboundary harm from hazardous activities," the "effects of armed conflicts on treaties," and the "expulsion of aliens" (the last adopted to date only on first reading). Even so, a countertrend has become evident. In 2006, the Commission completed three projects that were not described as "draft articles": the "draft principles on the allocation of

${ }^{4}$ Draft articles on the Law of Treaties: Text as Finally Adopted by the Commission, 21 U.N. GAOR, 21st Sess. Supp. No. 9, at 1, U.N. Doc. A/6309/Rev. 1(1966), reprinted in [1966] 2 Y.B. INT’L L. CoMm’N 177, U.N. Doc. A/CN.4/190.

5 Int'l Law Comm'n, Draft articles on Jurisdictional Immunities of States and their Property. Titles and texts adopted by the Drafting Committee on second reading: article 1 to 23, U.N. Doc. A/CN.4/SR.2218 to SR.2221 (1991), reprinted in [1991] 1 Y.B. INT'L L. Comm’n 66, U.N. Doc. A/CN.4/L.457.

${ }^{6}$ Rep. of the Int'l Law Comm'n, 53d Sess., Apr. 23-June 1, July 2-Aug. 10, 2001, U.N. Doc. A/56/10; GAOR, 56th Sess., Supp. No. 10 (2001).

7 David D. Caron, The ILC Articles on State Responsibility: The Paradoxical Relationship Between Form And Authority, 96 AJIL 857 (2002).

8 Rep. of the Int'l Law Comm'n, 63d Sess., Apr. 26-June 3, July 4-Aug. 12, 2011, U.N. Doc. A/66/10; GAOR, 66th Sess., Supp. No. 10 (2011).

${ }^{9} \underline{I d}$.

${ }^{10}$ Rep. of the Int'l Law Comm'n, 60th Sess., May 5- June 6, July 7-Aug. 8, 2008, U.N. Doc. A/63/10; GAOR, 63d Sess., Supp. No. 10 (2008).

${ }^{11}$ Rep. of the Int'l Law Comm'n, 58th Sess., May 1-June 9, July 3-Aug. 11, 2006, U.N. Doc. A/61/10; GAOR, 61st Sess., Supp. No. 10 (2006). 
loss in the case of transboundary harm arising out of hazardous activities," the "Guiding Principles" on the unilateral acts of states, and the "conclusions" on the fragmentation of international law. Five years later, in 2011, the Commission completed its "Guide to Practice on Reservations to Treaties." Since they were not draft articles, when the Commission reported these documents to the General Assembly it did not recommend the convening of a diplomatic conference. Instead, it "commended [the Commission's work] to the attention of the General Assembly" (as it did with the conclusions on fragmentation and the guiding principles on unilateral acts of states), asked the Assembly to "take note of [the Commission's work] and ensure its widest possible dissemination" (as it did with the Guide to Practice on Reservations), or asked the Assembly to "endorse the [Commission's work] by a resolution and urge States to take national and international action to implement" it (as it did with the draft principles on allocation of loss in the case of transboundary harm).

This move away from draft articles is especially evident in the Commission's current program of work, including the two topics that were added at its recent sixty-fifth session. Though the Commission is now crafting "draft articles" on the topics "immunity of state officials from foreign criminal jurisdiction" and "protection of persons in the event of disasters," this form is now distinctly in the minority. Last summer, the Commission provisionally adopted ${ }^{12}$ five "draft conclusions" on "subsequent agreements and subsequent practice in relation to the interpretation of treaties." It also decided, in the context of its project now titled "identification of customary international law," to "develop] . . . a set of conclusions with commentaries." On the topic of "provisional application of treaties," the Special Rapporteur "indicated that he considered the development of guidelines with commentaries to be an appropriate outcome of the consideration of the topic." On the topic "obligation to extradite or prosecute (aut dedere aut judicare)," the Commission seemed to be moving away from the draft articles that were proposed by a special rapporteur several years earlier. And on the topic "most-favoured-nation clause," the ILC Study Group "noted the possibility of developing for [its] final report guidelines and model clauses." (This is the Commission's second go-round with the topic. When it first considered MFN clauses in the 1960s and 70s, the project's outcome took the form of draft articles.) On "protection of the environment in relation to armed conflicts," a new topic, the Special Rapporteur "indicated that [she believed that it] was more suited to the development of non-binding draft guidelines than to a draft convention." The Commission also decided to include the topic "protection of the atmosphere" in its program of work "with the understanding that," inter alia, "[t]he outcome of the work on the topic will be draft guidelines." Only the topic "crimes against humanity," which the Commission placed on its long-term program of work on the basis of Professor Murphy's proposal (a fact that he modestly omits from his report in the Journal), would appear to be headed to the conventional outcome of draft articles for the purpose of an eventual treaty. As Professor Murphy put it in his syllabus on the topic, included as Annex B to the Commission's 2013 Report: "The objective of the International Law Commission on this topic ... would be to draft articles for what would become a Convention on the Prevention and Punishment of Crimes against Humanity."

The trends are clear: the Commission is using new forms for its work, and even when it uses the traditional form of draft articles, it is generally not recommending that its drafts be turned into treaties (and least not immediately), as it had customarily done in the past. Certainly the Commission has previously worked outside the form of draft articles, and it is also true that the Commission has not always recommended that its work be converted into treaties, but what before was an exception is now, seemingly, the rule, and vice versa.

Traditionally, the Commission conceived of its role as the originator-but not the finalizer-of important codification projects. The Commission would pass on its work to the General Assembly, which would either

${ }^{12}$ Rep. of the Int'l Law Comm'n, 65th Sess., May 6-June 7, July 8-Aug. 9, 2013, U.N. Doc. A/68/10; GAOR, 68th Sess., Supp. No. 10 (2013). 
take up the treaty drafting exercise itself or, more usually, convene a diplomatic conference for that purpose. As a result, states controlled the Commission's work product, deciding whether to codify an area of law and, if so, what the final formulation of that law would be. By not recommending the convening of treaty-drafting conferences (at least not in the first instance) and by reframing much of its work product as "draft guidelines," "draft conclusions," and "draft principles," the Commission is bypassing the direct control of states. Interestingly, the Commission's move in this direction has been acquiesced in by the General Assembly.

Though by no means giving up its traditional role entirely, by making this shift, the Commission, it seems, is envisioning for itself a wider audience, one made up not just of states, but also of attorneys, judges, policymakers, and academics. Indeed, the Commission explained ${ }^{13}$ its decision to develop "conclusions with commentaries" on the topic "customary international law" by noting that such "a practical outcome . . . would serve as a guide to lawyers and judges who are not experts in public international law." By taking this approach, the Commission is recognizing a broader range of international actors than it has before and perhaps as well a different (and softer) method of international lawmaking.

If all this is true, then why is the Commission taking these steps now, and is the Commission's move in this direction appropriate? Perhaps the Commission's motivation for changing the form of its work product is a consequence of its assessment that states, for a variety of reasons, are no longer interested in working through the treaty form. ${ }^{14}$ Perhaps too, as Professor Murphy writes in a forthcoming article 15 , "other forms for 'packaging' the ILC's work may be necessary for the ILC to remain relevant." The Commission's recent actions certainly warrant further study and critical thinking.

${ }^{13} \underline{I d}$.

14 Emily Cumberland, Call for Papers: "The End of Treaties? An Online Agora", 108 AJIL Unbound (Feb. 2014), available at http://www.asil.org/blogs/call-papers-end-treaties-online-agora.

15 Sean D. Murphy, Deconstructing Fragmentation: Koskenniemi's 2006 ILC Project, 27 TEMP. INT’L \& COMP. L.J. 293 (2013). 